\title{
Preparation of Nano-hydroxyapatite Obtained from Lates Calcarifer Fish Bone by Alkaline Hydrolysis Method
}

\author{
Le Ho Khanh Hy*, Dao Viet Ha, Pham Xuan Ky, Nguyen Phuong Anh, Phan Bao Vy, \\ Doan Thi Thiet
}

Institute of Oceanography, Vietnam Academy of Science and Technology (VAST), Nha Trang, Khanh Hoa, Vietnam

Email address:

lehokhanhhy@gmail.com (Le Ho K. Hy)

${ }^{*}$ Corresponding author

To cite this article:

Le Ho Khanh Hy, Dao Viet Ha, Pham Xuan Ky, Nguyen Phuong Anh, Phan Bao Vy, Doan Thi Thiet. Preparation of Nano-hydroxyapatite Obtained from Lates Calcarifer Fish Bone by Alkaline Hydrolysis Method. American Journal of Chemical and Biochemical Engineering. Vol. 5, No. 1, 2021, pp. 32-40. doi: 10.11648/j.ajcbe.20210501.15

Received: May 20, 2021; Accepted: June 11, 2021; Published: June 22, 2021

\begin{abstract}
Fish bone by-products are considered as abundant and cheap sources of Hydroxyapatite (HAp). The preparation of HAp powders from fish bones not only contributes to improving the added value of by-products but also reduces undesirable impacts on the environment. In this study, nano-HAp was successfully obtained from Lates calcarifer fish bone originated from a seafood export company in Khanh Hoa province. After pretreatment of fish bones for removing organic matters, the bones were under alkaline hydrolysis at $200^{\circ} \mathrm{C}$ within different time intervals of 30 mins, 1 and 1.5 hours. Results of XRD and SEM analysis showed that the calcium formed was HAP and it possessed an average size of 50-64 $\mathrm{nm}$. The values of the Ca/P molar ratio from 1.896 to 1.921 prove that the nano-HAp powders are B-type biological hydroxyapatites which have been confirmed by FTIR spectrum. In addition, the contents of heavy metals such as $\mathrm{As}, \mathrm{Pb}, \mathrm{Hg}, \mathrm{Cd}$ are measured by emission spectrophotometer and detected within safety limits of regulatory requirements of Vietnam regulation and US Pharmacopeia for food and dietary supplement standard. These properties show that nano-HAp from Lates calcarifer fish bone are applicable and to be used as an input material in food and medicine field.
\end{abstract}

Keywords: Lates Calcarifer Fish Bone, Alkakine Hydrolysis, $200^{\circ} \mathrm{C}, 0.5 / 1 / 1.5$ Hours, Nanohydroxyapatite, B-type Biological Hydroxyapatite

\section{Introduction}

Calcium hydroxyapatite, also known as hydroxyapatite (HAp), is a natural calcium phosphate with high biological compatibility with cells and tissues [1]. The chemical formula of HAp is $\mathrm{Ca}_{10}\left(\mathrm{PO}_{4}\right)_{6}(\mathrm{OH})_{2}$, and it is the main ingredient in human and animal bones and teeth (up to $60-70 \%$ by weight in bones [2]; and $97 \%$ in teeth [3]). HAp has the Ca/P molar ratio similar to that in bones and teeth $(\mathrm{Ca} / \mathrm{P}=1.67)[4,5]$. With the above valuable properties, HAp in the fine powder, super fine, porous, and film form has been studied to expand their applicability. HAp is currently being employed as a calcium supplement [6]; as surgical materials used in bone and tooth implants [4, 7, 8]; and as an absorbent material [9]; and in regeneration of cranial defects [10].

HAp can be obtained by two main ways: (1) synthesis from compounds containing calcium and phosphorus [6]; (2) extraction from natural sources including corals [11-13], cuttlefish bones [14-18], seashells from clams, oysters, snails [19-23], eggshell [24, 25], mammalian bone (e.g. bovine [26, 27], camel and horse [28]), fish scales [29-32], and fish bones [33-36]. If HAp products are prepared by the synthetic method, the resulting HAp has many different shapes and sizes depending on the reaction conditions. A disadvantage of this method is that it requires purification steps to remove the by-products that may affect the product quality and do possible harm to users [37]. On the other hand, HAp extracted from natural sources has high purity and biological compatibility, so it can be substituted for artificial HAp.

In recent years, millions of tons of fish are caught each year for human consumption, but only $50-60 \%$ of the total catch is used, and the rest is discarded [33]. Accompanying the increase in seafood products contributing to economic 
development, the seafood processing industry generates a large number of by-products. If not handled carefully, these by-products will be a big challenge for the environment. However, these by-products are the raw materials to extract valuable compounds for human life. Therefore, the bones of many fish species have been used to separate HAp by different methods such as swordfish (Xiphia gladius) and tuna (Thunnus thynnus) [34], cod fish [35], Japanese sea bream [38], salmon [39], grouper [40], tilapia [41], skipjack tuna (Katsuwonus pelamis) [42].

Recently in Vietnam, there is an abundant source to extract HAp: seabass. Seabass is being raised by two main methods: farming in the mud areas or in cages at sea. These fishes are cultured along the coasts of Quang Ninh, Hai Phong, Thua Thien - Hue, Quang Nam, Da Nang, Binh Dinh, Khanh Hoa, Binh Thuan, Ba Ria - Vung Tau and Spratly archipelago (Source of Vietnam Fisheries Newspaper, 2018). The total production is estimated to reach 4382 tons of seabass culture by 2014. After the fillets are being exported to the US, Europe, Taiwan and South Korea (Source of Science and Technology Associations of Khanh Hoa province, 2014), the amount of fish bone by-products that is left is an abundant source for extracting HAp. It has been well-known that the extraction of HAp by the thermal calcination method is a traditional way [8]. Another method, the alkaline hydrolysis, is also a route to obtain nanostructured HAp and carbonated HAp without the milling process [43]. On the basis of these observations, in our paper, we have studied HAp isolation from seabass Lates calcarifer bone through the alkaline hydrolysis method within different time intervals of $30 \mathrm{mins}$, 1 and 1.5 hours at $200^{\circ} \mathrm{C}$. The present study is intended for the preparation of HAp directly from fish bone for various biomedical applications.

\section{Materials and Methods}

\subsection{Fish Bone Treatment}

Lates calcarifer seabass bone after being filleted and head cut off were purchased at $\mathrm{T}$ and $\mathrm{H}$ Company Limited (Vinh Phuong ward, Nha Trang City, Khanh Hoa Province, Vietnam) in January 2021. The fish bones were then kept on ice, and transported to the laboratory of the institute of oceanography. Next, the seabass bones are boiled for 1 hour to remove the remaining soft tissue and washed with tap water to remove the remaining muscle, and this process is repeated several times until obtaining white bones. The bones were then dried at room temperature to constant mass.

The washed bones were then boiled with $1.0 \% \mathrm{NaOH}$ and acetone (the bone: solution=1:50) to remove protein, lipids, oils and organic impurities that still adhered. After being washed continuously with water until the $\mathrm{pH}$ was neutral, the bones were ground in a mortar pestle and then dried at $60^{\circ} \mathrm{C}$ for $24 \mathrm{~h}$ to obtain powder for the next experiment.

\subsection{Alkaline Hydrolysis of Fish Bone}

The bone powder was treated under alkaline hydrolysis following the protocol that was developed by Venkatesan et al. (2015) with some modifications [39]. Briefly, the bone powder was heated in $2 \mathrm{M} \mathrm{NaOH}$ (the bone powder: solution=1: 30 ) for 30 minutes, 1 and 1.5 hours at $200^{\circ} \mathrm{C}$. This mixture was then filtered by a pump and rinsed continuously with water until the $\mathrm{pH}$ was neutral. The resulting product was dried in an oven at $60^{\circ} \mathrm{C}$ until constant mass.

\subsection{Characterisation Techniques}

The stretching frequencies of the resulting samples were examined by Fourier transform infrared spectroscopy (FTIR) (Bruker Equinox 55). The phase and crystallinity were evaluated using an x-ray diffractometer (D2 Pharser-Brucker). The resultant XRD spectra were compared with the literature profile from the International Centre for Diffraction Data (ICDD 00-009-0432) to identify the hydroxyapatite compound.

The particle size and morphology of the hydroxyapatite compound were observed by a scanning electron microscope (Hitachi S-4800). The average crystal size is calculated using Image J software $1.48 \mathrm{~V}$ with the scale bar in the image, and this value is expressed as the mean $\pm \mathrm{SE}$.

The heavy metals such as $\mathrm{Pb}, \mathrm{Hg}, \mathrm{Cd}$, As and the calcium and phosphor were measured by emission spectrophotometer (Agilent 7700x-LC-MS).

\section{Results and Discussion}

\subsection{General Description of Nano-HAp Powder}

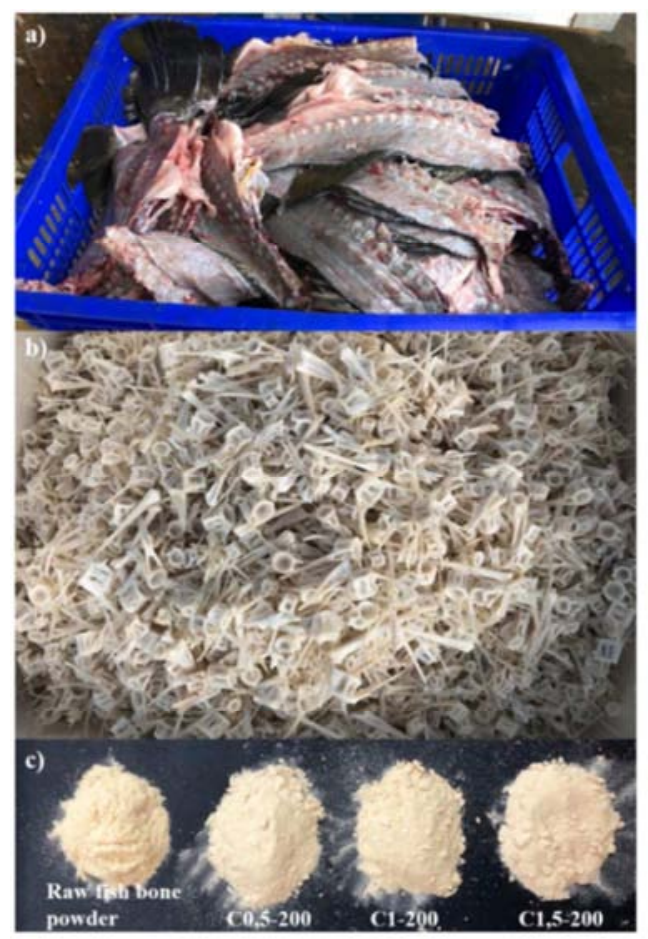

Figure 1. a) Lates calcarifer seabass bone; b) white bones after removing all organic matters; c) Raw fish bone powder and calcium powder samples obtained by alkaline hydrolysis at $200^{\circ} \mathrm{C}$ for different times $(0.5 ; 1 ; 1.5$ hours). 
Figure 1 depicts the outward appearance of the original Lates calcarifer seabass bone by-products (a); white bone after tissue removal (b) and calcium hydroxyapatite powder after heating at $200^{\circ} \mathrm{C}$ in different times (c). Figure 1c shows that the powder material before alkaline hydrolysis is fine, yellowish in colour; while calcium hydroxyapatite powder formed at $200^{\circ} \mathrm{C}$ in different time periods is more yellow in colour, smooth, odourless and tasteless.

\subsection{Stretching Frequency of $\mathrm{HAp}$}

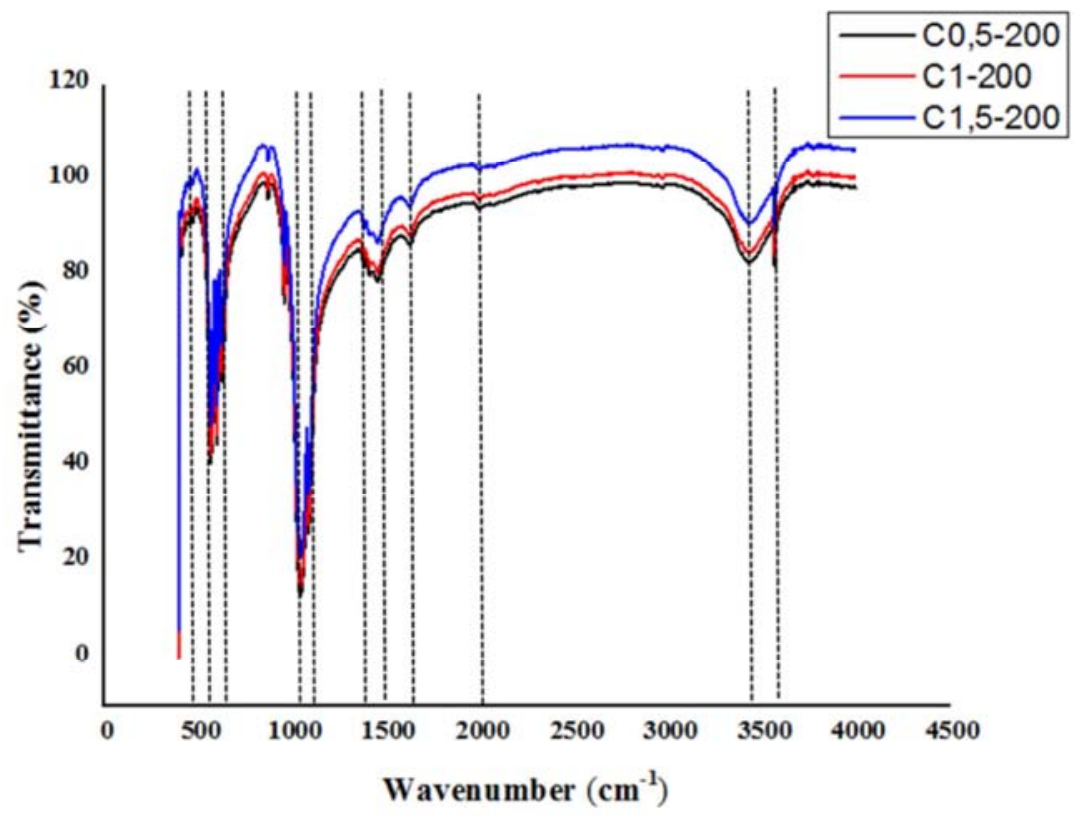

Figure 2. Infrared spectrum of hydroxyapatite formed under alkaline hydrolysis method at $200^{\circ} \mathrm{C}$ in different time periods.

(Black: C0,5-200 is sample obtained at $200^{\circ} \mathrm{C}$ for 0.5 hour; Red: $\mathrm{C} 1-200$ is sample obtained at $200^{\circ} \mathrm{C}$ for 1 hour; $\mathrm{Blue:} \mathrm{C} 1,5-200$ is sample obtained at $200^{\circ} \mathrm{C}$ for 1.5 hours).

Table 1. Stretching frequency of samples formed at $200^{\circ} \mathrm{C}$ in different time periods.

\begin{tabular}{|c|c|c|c|c|}
\hline \multirow{2}{*}{ Samples } & & 0.5 hour & 1 hour & 1.5 hours \\
\hline & & \multicolumn{3}{|c|}{ Wavenumber $\left(\mathrm{cm}^{-1}\right)$} \\
\hline \multirow{4}{*}{$\mathrm{PO}_{3}^{4-}$} & v3 & 1091,1049 & 1089,1051 & 1091,1051 \\
\hline & v1 & 961 & 962 & 962 \\
\hline & v4 & $633,602,571$ & $632,601,571$ & $633,603,570$ \\
\hline & v2 & 473 & 471 & 471 \\
\hline \multirow{2}{*}{\multicolumn{2}{|c|}{$\mathrm{OH}$}} & 3431,3571 & 3434,3570 & 3431,3571 \\
\hline & & $1418 \rightarrow 1461$ & $1413 \rightarrow 1462$ & $1414 \rightarrow 1457$ \\
\hline \multicolumn{2}{|l|}{$\mathrm{CO}_{3}{ }^{2-}$} & 2009 & 2010 & 2004 \\
\hline \multicolumn{2}{|l|}{$\mathrm{C}-\mathrm{H}$} & 2975 & 2977 & 2977 \\
\hline
\end{tabular}

IR spectra of samples formed under alkaline hydrolysis at $200^{\circ} \mathrm{C}$ in different time periods $(0.5,1$ and 1.5 hours $)$ are shown in Figure 2 and Table 1. All of these spectra are expressing the similarity of absorption peaks at different functional groups of HAp $\mathrm{Ca}_{10}\left(\mathrm{PO}_{4}\right)_{6}(\mathrm{OH})_{2}$ including $\mathrm{PO}_{3}{ }^{4-}$ and $\mathrm{OH}$. This result is identical to previous studies on swordfish bones (Xiphia gladius), tuna (Thunnus thynnus) [34] and on salmon bones [39].

Specifically, the IR spectrum of sample at $200^{\circ} \mathrm{C}$ in 0.5 hour (similar to that of samples at $200^{\circ} \mathrm{C}$ for 1 and 1.5 hours) shows the absorption peaks characteristic of $\mathrm{PO}_{3}{ }^{4-}$ group including three main regions. The first region is represented by the peaks of $1091,1049 \mathrm{~cm}^{-1}$ corresponding to v3 stretching mode and $961 \mathrm{~cm}^{-1}$ associated to $\mathrm{v} 1$ stretching mode. The second zone of phosphate ions exhibits the welldefined peaks at 633,602 and $571 \mathrm{~cm}^{-1}$ corresponding to v4 bending mode. The third region is observed a weak absorption peak at $473 \mathrm{~cm}^{-1}$ corresponding to $\mathrm{v} 2$ bending mode. Hydroxyl stretching mode is observed on all sample spectra at 3571 and $3431 \mathrm{~cm}^{-1}$ with a very low intensity peak. In addition to the absorption peaks of the functional groups present in the structure of HAp, three vibrational bands of carbonate ions are observed: a) peak at $875 \mathrm{~cm}^{-1}$; b) peaks from 1418 to $1461 \mathrm{~cm}^{-1} \mathrm{~cm}$ and c) peak at $2009 \mathrm{~cm}^{-1}$. The absorption of $\mathrm{CO}_{2}$ in the atmosphere during the experiment is responsible for the formation of carbonate ions [44]. Finally, the presence of organic material $(\mathrm{C}-\mathrm{H})$ is detected as a very low intensity peaks at $2975 \mathrm{~cm}^{-1}$. 


\subsection{XRD Analysis}

Figures 3 to 5 show a schematic diagram of the X-ray diffraction of samples. Figures 3, 4, 5 (a) present the results of each spectrum of samples at $200^{\circ} \mathrm{C}$ for 3 different time periods of $0.5,1$, and 1.5 hours and figures $3,4,5$ (b) insert XRD spectrum of samples with standard diagram of synthetic hydroxyapatite $\mathrm{HAp} \mathrm{Ca}_{10}\left(\mathrm{PO}_{4}\right)_{6}(\mathrm{OH})_{2}$ (ICDD 00-009-0432).

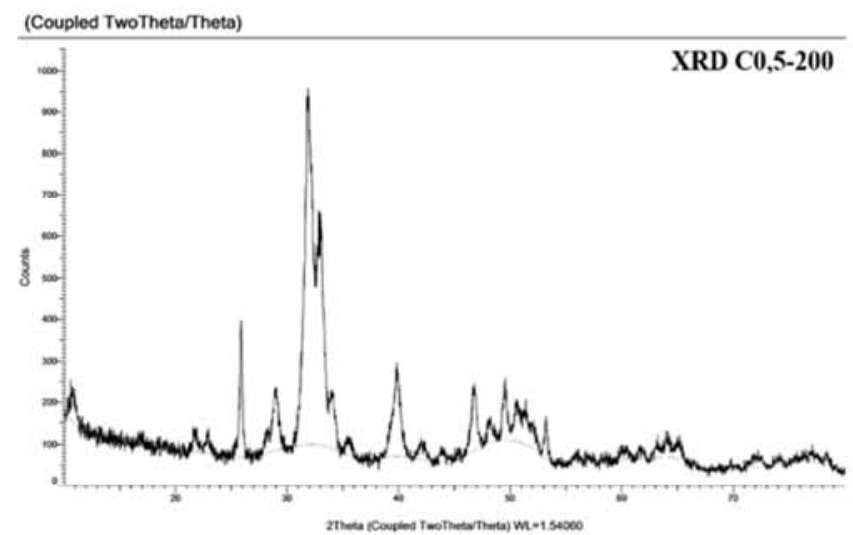

(a)
Accordingly, when comparing the schematic of samples with the standard pattern of HAp, these calcium samples consisted of HAp phase only with peaks that completely coincided with the standard and in previous studies [34, 45, 46]. However, regarding crystallinity degree of nano-HAp, these peaks were broad and not sharp, indicating that the nanoparticles were formed in small sizes.

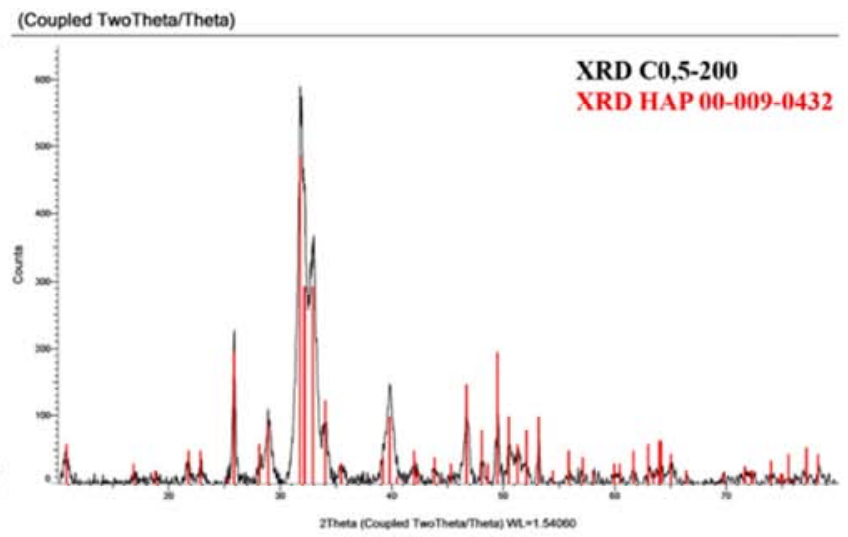

(b)

Figure 3. XRD schematic diagram of calcium sample at $200^{\circ} \mathrm{C}$ in 0.5 hour; b) Comparison of XRD schematic diagram of calcium sample at $200^{\circ} \mathrm{C}$ in 0.5 hour with that of HAp standard $\mathrm{Ca}_{10}\left(\mathrm{PO}_{4}\right)_{6}(\mathrm{OH})_{2}$.

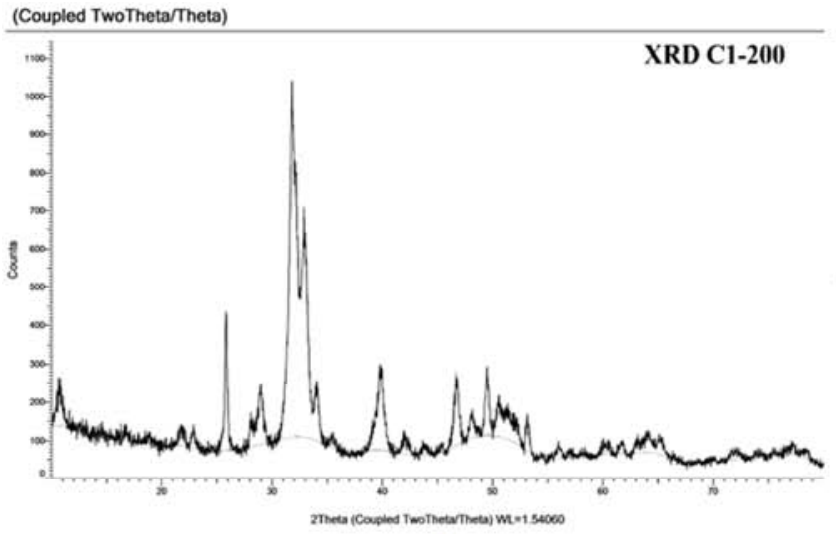

(a)

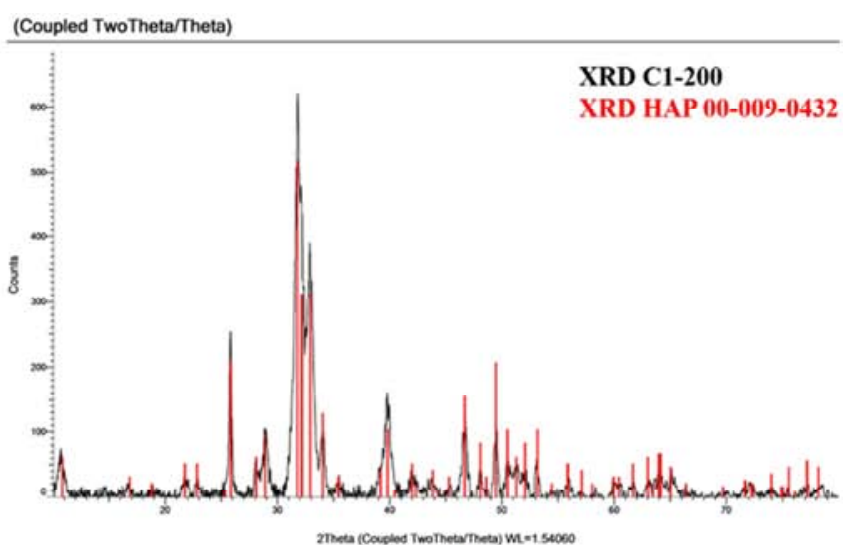

(b)

Figure 4. XRD schematic diagram of calcium sample at $200^{\circ} \mathrm{C}$ in 1 hour; b) Comparison of XRD schematic diagram of calcium sample at $200^{\circ} \mathrm{C}$ in 1 hour with that of HAp standard $\mathrm{Ca}_{10}\left(\mathrm{PO}_{4}\right)_{6}(\mathrm{OH})_{2}$.

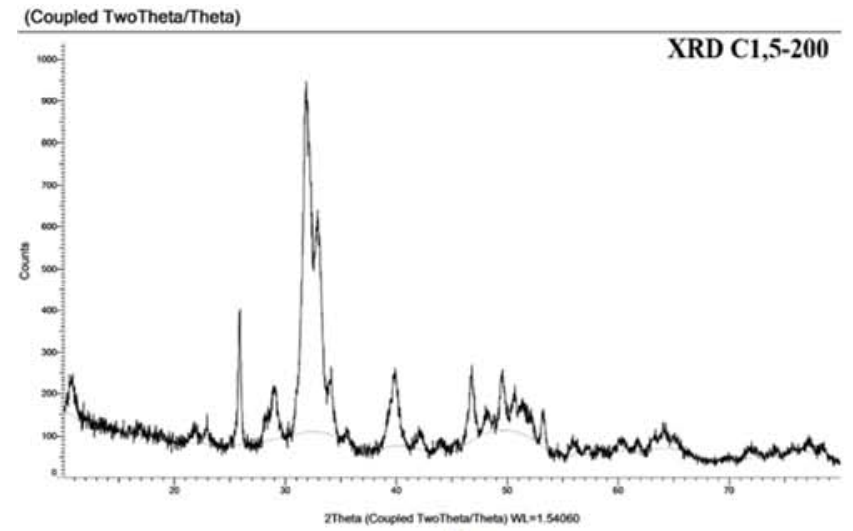

(a)

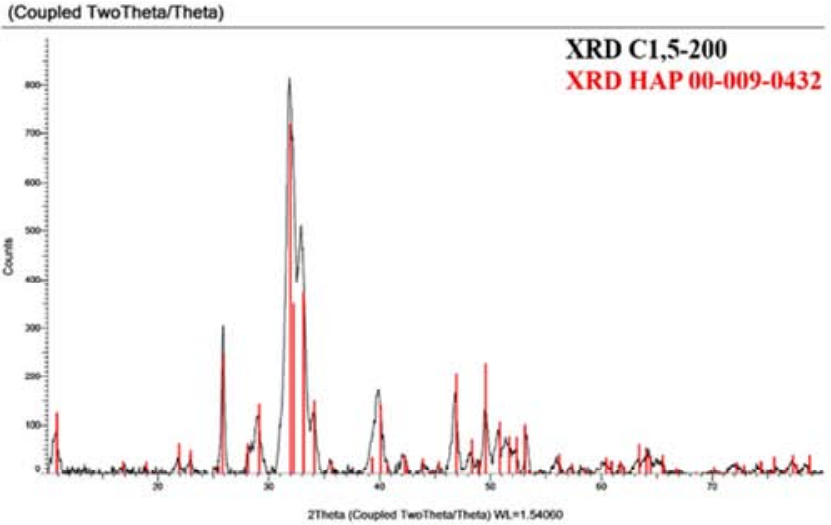

(b)

Figure 5. XRD schematic diagram of calcium sample at $200^{\circ} \mathrm{C}$ in 1.5 hour; b) Comparison of XRD schematic diagram of calcium sample at $200^{\circ} \mathrm{C}$ in 1.5 hour with that of HAp standard $\mathrm{Ca}_{10}\left(\mathrm{PO}_{4}\right)_{6}(\mathrm{OH})_{2}$. 


\subsection{SEM Analysis}

Figures $6,7,8$ show the SEM images of nano-HAp powder obtained after alkaline hydrolysis at $200^{\circ} \mathrm{C}$ in $0.5 ; 1$;
1.5 hours. These SEM images at different positions and different magnifications showed that the calcium crystals are mainly flattened, messy-structured particles, which tend to stick together.

Table 2. Average size in length and with (nm) of nano-HAp powder after alkaline hydrolysis at $200^{\circ} \mathrm{C}$ in $0.5 ; 1 ; 1.5$ hours

\begin{tabular}{lll}
\hline & Average size in length $(\mathbf{n m})$ & Average size in width $(\mathbf{n m})$ \\
\hline $\mathrm{C} 0,5-200$ & $51.63 \pm 14.83$ & $13.69 \pm 4.49$ \\
$\mathrm{C}-200$ & $45.73 \pm 12.54$ & $14.05 \pm 2.93$ \\
$\mathrm{C} 1,5-200$ & $53.24 \pm 17.09$ & $12.59 \pm 3.39$ \\
\hline
\end{tabular}

Previous studies have shown that the alkaline hydrolysis resulted in HAp with less crystallinity producing small size particles [47]. In this study, image $J$ software showed that the particles have an average size from 45 to $53 \mathrm{~nm}$ in length and 12 to $14 \mathrm{~nm}$ in width (Table 2), and it has been observed that the alkaline hydrolysis time did not affect the average size of HAp. The reason is that the assemblage of nanoparticles did not occur during alkaline hydrolysis time. Therefore, the alkaline hydrolysis method is the best approach for producing nanostructured HAp.
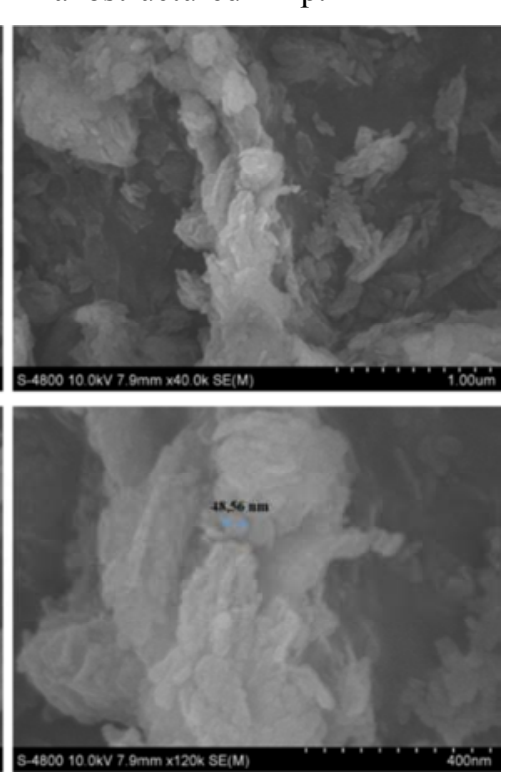

Figure 6. Scanning electron microscope image of HAp at $200^{\circ} \mathrm{C}$ in 0.5 hour at different magnifications: a) $7.9 \mathrm{~mm} \times 30.0 \mathrm{k}$; b) $7.9 \mathrm{~mm} \times 40.0 \mathrm{k}$; c) $7.9 \mathrm{~mm} \times 80.0 \mathrm{k}$; d) $7.9 \mathrm{~mm} \times 120 \mathrm{k}$.
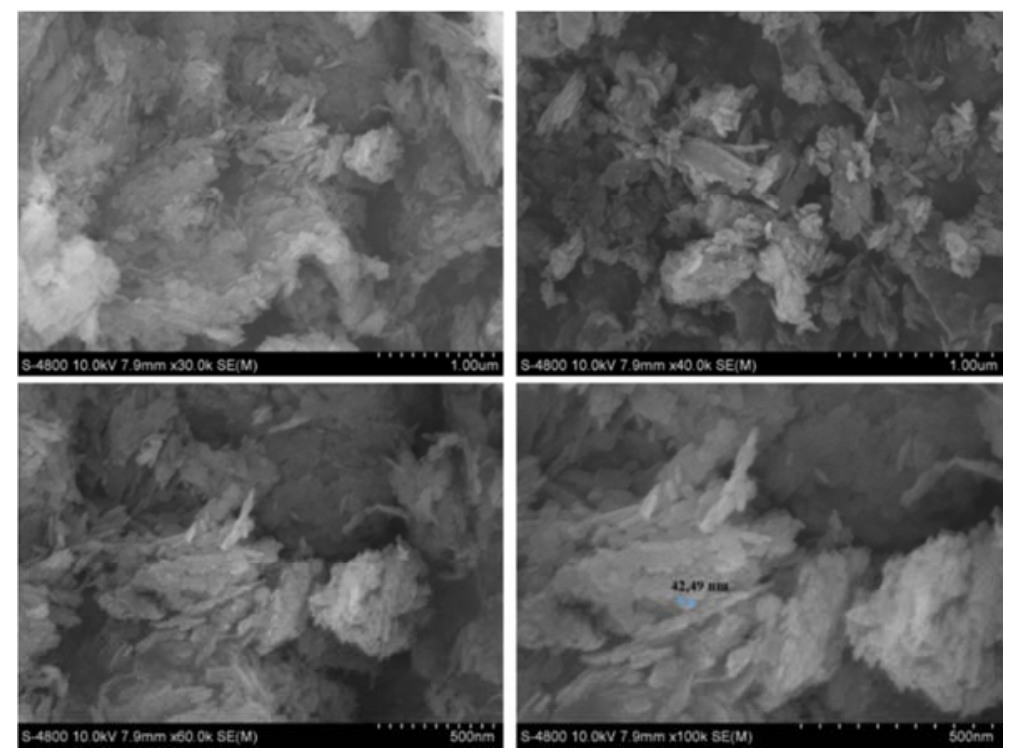

Figure 7. Scanning electron microscope image of $\mathrm{HAp}$ at $200^{\circ} \mathrm{C}$ in 1 hour at different magnifications: a) $\left.\left.7.9 \mathrm{~mm} \times 30.0 \mathrm{k} ; \mathrm{b}\right) 7.9 \mathrm{~mm} \times 40.0 \mathrm{k} ; \mathrm{c}\right) 7.9 \mathrm{~mm} \times 60.0 \mathrm{k}$; d) $7.9 m m \times 100 k$. 

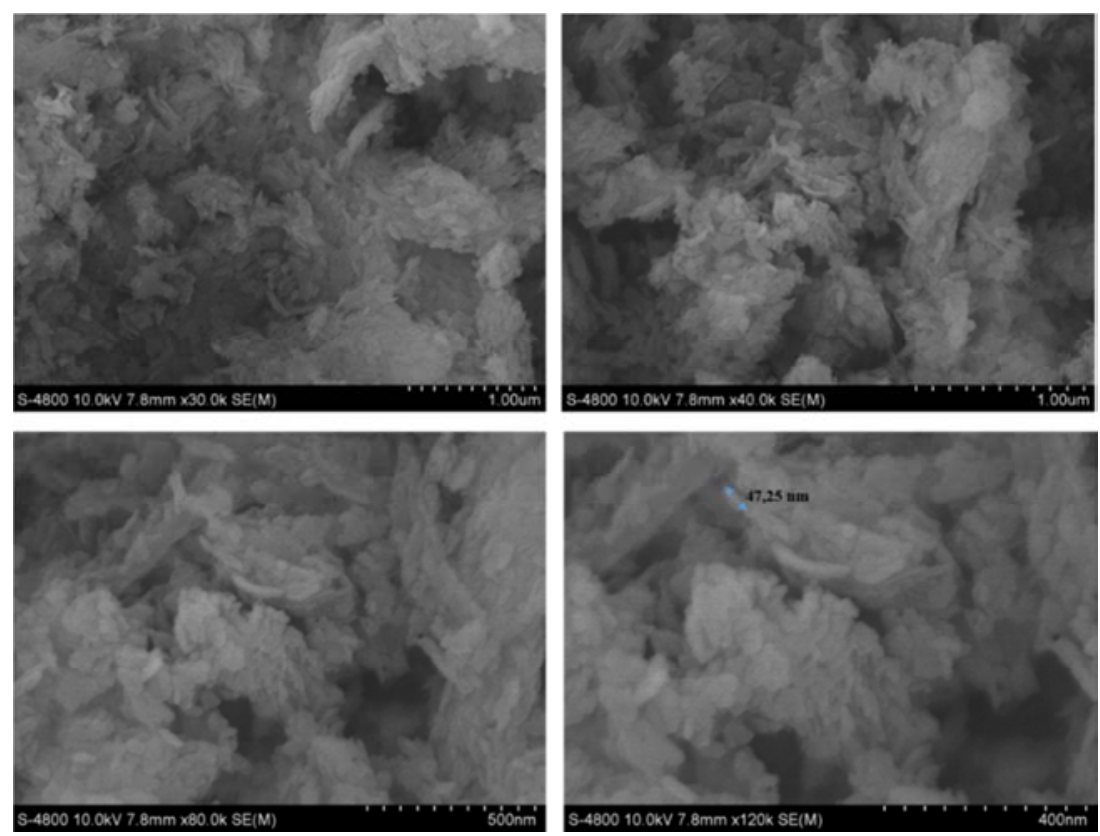

Figure 8. Scanning electron microscope image of HAp at $200^{\circ} \mathrm{C}$ in 1.5 hours at different magnifications: a) $7.9 \mathrm{~mm} \times 30.0 \mathrm{k}$; b) $7.9 \mathrm{~mm} \times 40.0 \mathrm{k}$; c) $7.9 \mathrm{~mm} \times 80.0 \mathrm{k}$; d) $7.9 \mathrm{~mm} \times 100 \mathrm{k}$.

\subsection{Elemental Composition}

Table 3. Elemental composition and the Ca/P molar ratios of resulted samples.

\begin{tabular}{|c|c|c|c|c|c|c|c|}
\hline \multirow{2}{*}{ Samples } & \multicolumn{6}{|c|}{ Elemental composition } & \multirow{2}{*}{$\begin{array}{l}\text { Ca/P } \\
\text { molar ratios }\end{array}$} \\
\hline & As (mg/kg) & $\mathrm{Pb}(\mathrm{mg} / \mathrm{kg})$ & $\mathrm{Hg}(\mathrm{mg} / \mathrm{kg})$ & $\mathrm{Cd}(\mathrm{mg} / \mathrm{kg})$ & Ca (\%) & $\mathbf{P}(\%)$ & \\
\hline $\mathrm{C} 0,5-200$ & 0.110 & 0.160 & ND & ND & 34.5 & 14.1 & 1.896 \\
\hline C1-200 & 0.130 & 0.170 & ND & ND & 34.9 & 14.2 & 1.905 \\
\hline C1,5-200 & 0.080 & 0.090 & ND & ND & 34.7 & 14 & 1.921 \\
\hline
\end{tabular}

ND: not detected

The threshold of method detection for Cd is $0.02 \mathrm{mg} / \mathrm{kg}$

The threshold of method detection for $\mathrm{Hg}$ is $0.01 \mathrm{mg} / \mathrm{kg}$

Table 3 shows the evaluation of heavy metals ( $\mathrm{As}, \mathrm{Pb}, \mathrm{Hg}$, $\mathrm{Cd})$ content $(\mathrm{mg} / \mathrm{kg})$ and elemental content of calcium and phosphorus (\%) in HAp samples formed at $200^{\circ} \mathrm{C}$ in $0.5,1$ and 1.5 hours by emission spectroscopy method. Hereby, these samples have the $\mathrm{Ca} / \mathrm{P}$ molar ratios ranging from 1.896 to 1.921 and these values are higher than that of human bones (1.67). This value is minimum when heated for at least $0.5 \mathrm{~h}$ and increases with longer heating ( 1 and 1.5 hours). The absorption of $\mathrm{CO}_{2}$ in the atmosphere during the experiment time and the alkaline environment during the process allowed the formation of carbonate ions in samples. Therefore, the longer the heating time was, the more carbonate ions were present and these ions then substituted phosphate sites leading to a B-type HAp. This type of carbonate apatite is a main constituent of the biological apatite [48]. The replacement of phosphate ion by carbonate ion is very important, because carbonated HAp has been found to be easily resorbed by living cells and to possess higher solubility than HAp with $\mathrm{Ca} / \mathrm{P}$ ratio of $1.67[49,50]$. Other authors have also observed the higher $\mathrm{Ca} / \mathrm{P}$ ratios in biological HAp obtained from swordfish bones (Xiphia gladius), tuna (Thunnus thynnus) [34] and cow bones [51]. In addition, the presence of carbonate ions of type B HAp in seabass Lates calcarifer bone was confirmed by FTIR spectroscopy (Section 3.2).

Table 4. Maximum accepted levels of heavy metals according to Vietnam regulation and US Pharmacopeia (USP).

\begin{tabular}{lll}
\hline $\begin{array}{l}\text { Heavy metals } \\
(\mathbf{m g} / \mathbf{k g})\end{array}$ & $\begin{array}{l}\text { Maximum accepted levels of } \\
\text { metals (mg/kg) according to } \\
\text { USP in Dietary Supplement } \\
\text { Standard [52] }\end{array}$ & $\begin{array}{l}\text { Maximum accepted levels of metals according to Vietnam National Technical Regulation } \\
\text { QCVN 8-2:2011/BYT regarding the maximum level of heavy metals allowed in food [53] and } \\
\text { to Vietnam Decision No. 46/2007/QD-BYT on promulgation regulation of maximum level of } \\
\text { biological and chemical pollution in food [54] }\end{array}$ \\
\hline $\mathrm{As}$ & 0.15 & 5 \\
$\mathrm{~Pb}$ & 0.5 & 3 \\
$\mathrm{Hg}$ & 1.5 & 0.1 \\
$\mathrm{Cd}$ & 2.5 & 1 \\
\hline
\end{tabular}

As described in Table 3, $\mathrm{Cd}$ and $\mathrm{Hg}$ were not detected in all three HAp powders. However, $\mathrm{Pb}$ and $\mathrm{As}$ contents in 
nano-HAp were respectively $0.09-0.170$ and $0.08-0.13 \mathrm{mg} / \mathrm{kg}$ and these levels met the regulatory requirements of Vietnam regulation and US Pharmacopeia (USP) for food and dietary supplement standard (Table 4).

The results of the $\mathrm{Ca} / \mathrm{P}$ molar ratios and the amount within the safe limits of heavy metals (As, $\mathrm{Pb}, \mathrm{Hg}$, and $\mathrm{Cd}$ ) show that nano-HAp powder from Lates calcarifer fish bone can be used as an input material for medicine and dietary supplements foods. However, evaluation of acute toxicity in mice and subchronic toxicity in rabbits of this product is required and this experiment is in progress in order to investigate the potential toxicity before mass production in large scale.

\section{Conclusion}

In our study, nano-HAp powders from Lates calcarifer seabass bone was successfully obtained when heated in $2 \mathrm{M}$ $\mathrm{NaOH}$ for 30 minutes, 1 and 1.5 hours at $200^{\circ} \mathrm{C}$. The average size of particles are from 45 to $53 \mathrm{~nm}$ in length and 12 to 14 $\mathrm{nm}$ in width, and the heating time did not influence the particle size. The $\mathrm{Ca} / \mathrm{P}$ ratio ranged from 1.896 to 1.921 , indicating that this calcium powder was B-type HAp which was confirmed by FTIR spectrum. In addition, the heavy metal content of the calcium powder is completely within the allowable limits for dietary supplement and medicine.

\section{Conflict of Interest}

All the authors do not have any possible conflicts of interest.

\section{Acknowledgements}

We best gratitude to staff of Division of Aquaculture Technique, Institute of Oceanography, Viet Nam Academy of Science and Technology for providing the necessary facilities to carry out this work. This study was funded by Khanh Hoa province under project number ĐT-2019-40699-ĐL1.

\section{References}

[1] Huang, Y- C., Hsiao, P-C., Chai, H-J., 2011. Hydroxyapatite extracted from fish scale: Effects on MG63 osteoblast-like cells. Ceramics International 37 (6): 1825-1831.

[2] Nieh, T. G., Choi, B. W., and Jankowski, A. F., 2000. Synthesis and characterization of porous hydroxyapatite and hydroxyapatite coatings (No. UCRLJC-141229). Lawrence Livermore National Lab., CA (US).

[3] Robinson, C., Connell, S., Kirkham, J., Shore, R., and Smith, A., 2004. Dental enamel-a biological ceramic: regular substructures in enamel hydroxyapatite crystals revealed by atomic force microscopy. Journal of Materials Chemistry 14 (14): 2242-2248.

[4] Tang, P. F., Li, G., Wang, J. F., Zheng, Q. J., Wang, Y., 2009. Development, characterization, and validation of porous carbonated hydroxyapatite bone cement. Journal of Biomedical Materials Research. Part B, Applied Biomaterials
90: 886-893.

[5] Staffa, G., Nataloni, A., Compagnone, C., and Servadei, F., 2007. Custom made cranioplasty prostheses in porous hydroxy-apatite using 3D design techniques: 7 years experience in 25 patients. Acta Neurochirurgica 149 (2): 161170.

[6] Kano, S., Yamazaki, A., Otsuka, R., Ohgaki, M., Akao, M., Aoki, H., 1994. Application of hydroxyapatite-sol as drug carrier. Bio-Medical Materials and Engineering 4 (4): 283290.

[7] Hirata, A., Maruyama, Y., Onishi, K., Hayashi, A., Saze, M., Okada, E., 2008. A vascularized artificial bone graft using the periosteal flap and porous hydroxyapatite: Basic research and preliminary clinical application. Wound Repair and Regeneration 12 (1): A4.

[8] Venkatesan, J., Kim, S. K., 2010. Effect of temperature on isolation and characterization of hydroxyapatite from tuna (Thunnus obesus) bone. Materials 3 (10): 4761-4772.

[9] Reichert, J., Binner, J. G. P., 1996. An evaluation of hydroxyapatite-based filters for removal of heavy metal ions from aqueous solutions. Journal of Materials Science 31 (5): $1231-1241$

[10] Staffa, G., Nataloni, A., Compagnone, C., Servadei, F., 2007. Custom made cranioplasty prostheses in porous hydroxyapatite using 3D design techniques: 7 years experience in 25 patients. Acta Neurochirurgica 149 (2): 161-170.

[11] Roy, D. M., and Linnehan, S. K., 1974. Hydroxyapatite formed from coral skeletal carbonate by hydrothermal exchange. Nature 247 (5438): 220-222.

[12] White, E., and Shors, E. C., 1986. Biomaterial aspects of Interpore-200 porous hydroxyapatite. Dental Clinics of North America 30 (1): 49-67.

[13] Vu Duy Hien, Dao Quoc Huong, Phan Thi Ngoc Bich., 2010. Study of the formation of porous hydroxyapatite ceramics from corals via hydrothermal process. Vietnam journal of chemistry 48 (5): $591-596$ (In Vietnamese).

[14] a) Rocha, J. H. G., Lemos, A. F., Agathopoulos, S., Valério, P., Kannan, S., Oktar, F. N., and Ferreira, J. M. F., 2005. Scaffolds for bone restoration from cuttlefish. Bone 37 (6): 850-857. b) Rocha, J. H. G., Lemos, A. F., Kannan, S., Agathopoulos, S., and Ferreira, J. M. F., 2005. Hydroxyapatite scaffolds hydrothermally grown from aragonitic cuttlefish bones. Journal of Materials Chemistry 15 (47): 5007-5011.

[15] Rocha, J. H. G., Lemos, A. F., Agathopoulos, Kannan, S., Valério, P., Ferreira, J. M. F., 2006. Hydrothermal growth of hydroxyapatite scaffolds from aragonitic cuttlefish bones. Journal Biomedical Materials Research A 77 (1): 160-168.

[16] Sarin, P., Lee, S. J., Apostolov, Z. D., and Kriven, W. M., 2011. Porous biphasic calcium phosphate scaffolds from cuttlefish bone. Journal of the American Ceramic Society 94 (8): 2362-2370.

[17] Venkatesan, J., Rekha, P. D., Anil, S., Bhatnagar, I., Sudha, P. N., Dechsakulwatana, C., Kim, S.-K., Shim, M. S., 2018. Hydroxyapatite from Cuttlefish Bone: Isolation, Characterizations, and Applications. Biotechnology and Bioprocess Engineering 23: 383-393. 
[18] Faksawat, K., Sujinnapram, S., Limsuwan, P., Hoonnivathana, E., \& Naemchanthara, K., 2015. Preparation and Characteristic of Hydroxyapatite Synthesized from Cuttlefish Bone by Precipitation Method. Advanced Materials Research 1125: 421-425.

[19] Lemos, A. F., Rocha, J. H. G., Quaresma, S. S. F., Kannan, S., Oktar, F. N., Agathopoulos, S., and Ferreira, J. M. F., 2006. Hydroxyapatite nano-powders produced hydrothermally from nacreous material. Journal of the European Ceramic Society 26 (16): 3639-3646.

[20] Zhang, X., and Vecchio, K. S., 2006. Creation of dense hydroxyapatite (synthetic bone) by hydrothermal conversion of seashells. Materials Science and Engineering $C 26$ (8): $1445-1450$.

[21] Yang, Y., Yao, Q., Pu, X., Hou, Z., and Zhang, Q., 2011. Biphasic calcium phosphate macroporous scaffolds derived from oyster shells for bone tissue engineering. Chemical Engineering Journal 173 (3): 837-845.

[22] Pal, A., Maity, S., Chabri, S., Bera, S., Chowdhury, A. R., Das, M., Sinha, A., 2017. Mechanochemical synthesis of nanocrystalline hydroxyapatite from Mercenaria clam shells and phosphoric acid. Biomedical Physics and Engineering Express 3: 15010.

[23] Mohamad Razali, N. A. I., Pramanik, S., Abu Osman, N. A., Radzi, Z., Pingguan-Murphy, B., 2016. Conversion of calcite from cockle shells to bioactive nanorod hydroxyapatite for biomedical applications. Journal of Ceramic Processing Research 17: 699-706.

[24] Goloshchapov, D. L., Kashkarov, V. M., Rumyantseva, N. A., Seredin, P. V., Lenshin, A. S., Agapov, B. L., Domashevskaya, E. P., 2013. Synthesis of nanocrystalline hydroxyapatite by precipitation using hen's eggshell. Ceramics International 39: 4539-4549.

[25] Gutiérrez-Prieto, S. J., Fonseca, L. F., Sequeda-Castañeda, L. G., Díaz, K. J., Castañeda, L. Y., Leyva-Rojas, J. A., SalcedoReyes, J. C., Acosta, A. P., 2019. Elaboration and Biocompatibility of an Eggshell-Derived Hydroxyapatite Material Modified with Si/PLGA for Bone Regeneration in Dentistry. International Journal of Dentistry. Article ID 5949232, 12 pages.

[26] Barua E., Deb P., Das Lala S., Deoghare A. B., 2019. Extraction of Hydroxyapatite from Bovine Bone for Sustainable Development. Biomaterials in Orthopaedics and Bone Regeneration: 147-158.

[27] Ayatollahi, M. R., Yahya, M. Y., Shirazi, H. A., Hassan, S. A., 2015. Mechanical and tribological properties of hydroxyapatite nanoparticles extracted from natural bovine bone and the bone cement developed by nano-sized bovine hydroxyapatite filler. Ceramics International 41: 1081810827.

[28] Jaber, H. L., Hammood, A. S., Parvin, N. 2018. Synthesis and characterization of hydroxyapatite powder from natural Camelus bone. Journal of the Australian Ceramic Society 54: $1-10$.

[29] Ikoma, T., Kobayashi, H., Tanaka, J., Walsh, D., and Mann, S., 2003. Microstructure, mechanical, and biomimetic properties of fish scales from Pagrus major. Journal of Structural Biology 142 (3): 327-333.

[30] Mondal, S., Mahata, S., Kundu, S., and Mondal, B., 2010.
Processing of natural resourced hydroxyapatite ceramics from fish scale. Advances in Applied Ceramics 109 (4): 234-239.

[31] Pon-On, W., Suntornsaratoon, P., Charoenphandhu, N., Thongbunchoo, J., Krishnamra, N., Tang, I. M., 2016. Hydroxyapatite from fish scale for potential use as bone scaffold or regenerative material. Materials Science and Engineering C 62: 183-189.

[32] Zainol, I., Adenan, N. H., Rahim, N. A., Jaafar, C. N. A., 2019 Extraction of natural hydroxyapatite from tilapia fish scales using alkaline treatment. Materials Today: Proceedings 16: 1942-1948.

[33] Ozawa, M., and Suzuki, S., 2002. Microstructural development of natural hydroxyapatite originated from fishbone waste through heat treatment. Journal of the American Ceramic Society 85 (5): 1315-1317.

[34] Boutinguiza, M., Pou, J., Comesaña, R., Lusquiños, F., De Carlos, A., and León, B., 2012. Biological hydroxyapatite obtained from fish bones. Materials Science and Engineering C 32 (3): 478-486.

[35] Piccirillo, C., Silva, M. F., Pullar, R. C., da Cruz, I. B., Jorge, R., Pintado, M. M. E., and Castro, P. M., 2013. Extraction and characterisation of apatite-and tricalcium phosphate-based materials from cod fish bones. Materials Science and Engineering C 33 (1): 103-110.

[36] Nguyen Van Hoa, Nguyen Cong Minh, Pham Anh Dat. 2018. Preparation and characterization of nanohydroxyapatite from fish bones: (2) use of enzyme for pre-treatment. Journal of fisheries science and technology 2: 39-45. (In Vietnamese)

[37] Dao Quoc Huong, Pham Thi Sao. 2011. Synthesis of porous hydroxyapatite ceramics from limestone via hydrothermal process. Vietnam Journal of Science and Technology 49 (2): 93-99. (In Vietnamese).

[38] Ozawa, M., Suzuki, S., 2002. Microstructural developments of hydroxyapatite originated from fish bones waste though heat treatment. Journal American Ceramic Society 85 (5): 13151317.

[39] Venkatesan, J., Lowe, B., Manivasagan, P., Kang, K-H., Chalisserry, E. P., Anil, S., Kim, D-G., Kim, S-K., 2015. Isolation and Characterization of Nano-Hydroxyapatite from Salmon Fish Bone. Materials 8: 5426-5439.

[40] Dabiri, S. M. H., Rezaie, A. A., Moghimi, M., Rezaie, H., 2018. Extraction of Hydroxyapatite from Fish Bones and Its Application in Nickel Adsorption. BioNanoScience 8 (3): 823834.

[41] Mustafa, N., Ibrahim, M. H. I., Asmawi, R., 2014. Hydroxyapatite extracted from waste fish bones and scales via calcination method. Mechanics of Materials 2014: 1-4.

[42] Le Ho Khanh Hy, Pham Xuan Ky, Dao Viet Ha, Nguyen Thu Hong, Phan Bao Vy, Doan Thi Thiet, Nguyen Phuong Anh. 2018. Certain properties of calcium hydroxyapatite from skipjack tuna bone (Katsuwonus pelamis). Vietnam Journal of Marine Science and Technology 18 (4A): 151-163. (in Vietnamese)

[43] Venkatesan, J., Qian, Z.-J., Ryu, B., Kumar, N. A., Kim, S.-K., 2011. Preparation and characterization of carbon nanotubegrafted-chitosan- Natural hydroxyapatite composite for bone tissue engineering. Carbohydrate Polymers 83: 569-577. 
[44] Paz, A., Guadarrama, D., López, M., González, J. E., 2012. A comparative study of hydroxyapatite nanoparticles synthesized by different routes. Química Nova 35 (9): 17241727.

[45] S’lo'sarczyk, A., Paszkiewicza, Z. Paluszkiewicza, C., 2005. FTIR and XRD evaluation of carbonated hydroxyapatite powders synthesized by wet methods. Journal of Molecular Structure 744: 657-661.

[46] Berzina-Cimdina, L., Borodajenko, N., 2012. Research of Calcium Phosphates Using Fourier Transform Infrared Spectroscopy. INTECH Open Access Publisher.

[47] Venkatesan, J., Qian, Z.- J., Ryu, B., Thomas, N. V., Kim, S. K., 2011. A comparative study of thermal calcination and an alkaline hydrolysis method in the isolation of hydroxyapatite from Thunnus obesus bone. Biomedical Materials 6: 035003.

[48] Antonakos, A., Liarokapis, E., Leventouri, T., 2007. MicroRaman and FTIR studies of synthetic and natural apatites. Biomaterials 28 (19): 3043-3054.

[49] Redey, S. A., Razzouk, S., Rey, C., Bernache-Assollant, D., Leroy, G., Nardin, M., Cournot, G., 1999. Osteoclast adhesion and activity on synthetic hydroxyapatite, carbonated hydroxyapatite, and natural calcium carbonate: Relationship to surface energies. Journal of Biomedical Materials Research 45: $140-147$.
[50] Safarzadeha, M., Ramesha, S., Tan, C. Y., Chandran, H., Ching, Y. C., A. F. M., Noor, Krishnasamy, S., Teng, W. D., 2020. Sintering behaviour of carbonated hydroxyapatite prepared at different carbonate and phosphate ratios Comportamiento de sinterización de hidroxiapatita carbonatada preparada en diferentes proporciones de carbonato y fosfato. Boletín de la Sociedad Española de Cerámica y Vidrio 59 (2): 73-80.

[51] Joschek, S., Nies, B., Krotz, R. and Gopferich, A., 2000. Chemical and Physicochemical Characterization of Porous Hydroxyapatite Ceramics Made of Natural Bone. Biomaterials 21: $1645-1658$.

[52] The new USP $<232>$ (Elemental Impurities-Limits) and USP $<233>\quad$ (Elemental Impurities-Procedures) 2012 http://www.chemicalsolutionsltd.com/Cap_USP.htm.

[53] Vietnam National Technical Regulation QCVN 8-2: 2011/BYT regarding the maximum level of heavy metals allowed in food. https://apps.fas.usda.gov/newgainapi/api/report/downloadrepo rtbyfilename? filename $=$ Technical $\% 20$ Regulations $\% 20$ on $\% 20$ Mycotoxin\%20and\%20Heavy\%20Metals\%20MRLs\%20in\%2 0Foods\%20_Hanoi_Vietnam_12-10-2013.pdf.

[54] Decision No. 46/2007/QD-BYT on promulgation regulation of maximum level of biological and chemical pollution in food https:/vanbanphapluat.co/decision-no-46-2007-qd-byt-onpromulgation-regulation-of-maximum-level-of-biolo. 